\title{
COVID-19: Science and global health governance under attack
}

Less than 3 months after the World Health Organization (WHO) declared COVID-19 a Public Health Emergency of International Concern, ${ }^{[1]}$ and within a month of the WHO declaring COVID19 a global pandemic, ${ }^{[2]}$ COVID-19 infections and fatalities have grown exponentially, globally. Now, more than ever, the world needs responsible political leadership, evidence-based decision-making, and co-ordinated global health action. The USA, long considered the leader of the Global North, leads the world with COVID-19 infections, while South Africa (SA), a prominent state in the Global South and current Chair of the African Union, currently leads Africa's count of COVID-19 infections. Recent developments in these settings highlight that misguided ideology, partisan information flows, politics and pseudoscience pose a critical threat to science and undermine global health governance. In this time of global crisis, the world deserves better.

\section{A snapshot of the Global North: The USA}

On 18 March 2020, a misleading claim was made on the US television channel, Fox, suggesting that the results of a small trial on hydroxychloroquine - a decades-old antimalarial drug - demonstrated a ' $100 \%$ cure rate against coronavirus. ${ }^{\left[{ }^{3]}\right.}$ Within days, the US President, Donald Trump, began hailing the drug as a 'game changer' against COVID-19. ${ }^{[4]}$ The President has since doubled down on this position, ${ }^{[5]}$ without compelling scientific evidence ${ }^{[6]}$ triggering a surge in demand, hoarding and associated shortages for those who need the drug, ${ }^{[7]}$ and even deaths. ${ }^{[8]}$ Dr Anthony Fauci, the country's director of the National Institute of Allergies and Infectious Diseases, has openly and repeatedly warned that there is no conclusive evidence yet to support use of the drug for COVID-19 treatment. ${ }^{[9]}$ Fauci's candid COVID-19 forecasting for the USA has repeatedly contradicted rosier projections from the President. ${ }^{[10]}$ The country's far right have interpreted these remarks as attempts to undermine the President in an election year, and have responded with conspiracy theories. ${ }^{[10]}$ On 28 March 2020, the US Food and Drug Administration (FDA) issued an Emergency Use Authorisation to allow hydroxychloroquine sulfate and chloroquine phosphate products to be distributed and used for certain hospitalised patients with COVID-19, ${ }^{[11]}$ triggering an outcry from the scientific community. ${ }^{[12]}$ On 1 April 2020, the US Justice Department revealed that Fauci was being assigned nine special agents for enhanced personal security after receiving threats from the country's far right. ${ }^{[13]}$

Concurrently, notwithstanding the announcement of an official name for the virus responsible for COVID-19 - severe acute respiratory syndrome coronavirus 2 (SARS-CoV-2) - in February $2020,{ }^{[14,15]}$ the US President repeatedly labelled the virus the 'Chinese virus' or 'Wuhan virus, ${ }^{[16]}$ thereby racialising the virus, in defiance of guidance published by the WHO in 2015, cautioning against such characterisation. ${ }^{[17]}$ On 8 April 2020, in response to mounting criticism that the Trump administration was mismanaging the country's COVID-19 epidemic, Trump attacked the WHO, accusing it of being 'funded largely by the United States, yet very China centric', and getting the pandemic 'wrong. ${ }^{[18]}$ The President also threatened that the USA was 'going to put a hold on money spent to the WHO'. The WHO Director-General (DG), Dr Tedros Adhanom Ghebreyesus - who was subsequently subjected to racism and death threats - responded by calling for unity and the 'depoliticising' of the virus. ${ }^{[19,20]}$ The stance by the WHO DG exemplifies responsible moral leadership in a time of global crisis. The WHO DG has since highlighted a timeline of the WHO's response to the pandemic. ${ }^{[21]} \mathrm{On}$ 14 April 2020, Trump announced that he was halting funding to the WHO while a review was conducted of the WHO's 'role in severely mismanaging and covering up the spread of coronavirus. ${ }^{[22]}$

While the WHO's performance in managing the COVID-19 pandemic is not unassailable, ${ }^{[23]}$ Trump's decision to scapegoat the WHO in an attempt to distract attention away from his administration's domestic failings is morally repugnant, constitutes an assault on global health governance, endangers public health, and is akin to committing 'a crime against humanity.'[24]

\section{A snapshot of the Global South: South Africa}

On 5 March 2020, SA recorded its first case of COVID-19. After consulting with the country's corporate sector, organised labour, civil society and scientific community, on 15 March 2020, SA's President declared a national State of Disaster in response to rising COVID19 cases in the country. ${ }^{[25]}$ With COVID-19 cases rising despite restrictive social/physical distancing measures being imposed, the President subsequently imposed a nationwide lockdown on 23 March 2020, effective 26 March 2020. ${ }^{[26]}$ While the government's decisive action at a relatively early stage in the country's COVID-19 epidemic has drawn widespread praise, ${ }^{[27]}$ support for the lockdown was not universal. Soon after the lockdown was announced, an obscure local NGO bought an urgent application to the country's apex court, requesting direct access to the court so that it could argue against the lockdown on the grounds that the country was not facing an emergency situation due to COVID-19 not being harmful to Africans, and characterising COVID-19 as a 'self-healing disease for Africans. ${ }^{[28]}$ The founding affidavit filed in support of the application revealed that the NGO's stance was based on misinterpreted credible media sources, ${ }^{[29]}$ as well as dubious sources. ${ }^{[30]}$ While the country's apex court dismissed the application, ruling that it had 'no prospects of success, ${ }^{\text {, }}{ }^{[8]}$ the matter revealed that charlatans were peddling scientific falsehoods and that such information was being misused for misguided political and ideological ends. Since then, rising COVID19 cases throughout Africa ${ }^{[31]}$ and among black people in the USA ${ }^{[32]}$ overwhelmingly confirm that Africans are at equal risk of the disease.

SA recently extended its lockdown ${ }^{[33]}$ on the basis of scientific evidence. ${ }^{[34]}$ This is an example of evidence-based decision-making and responsible leadership, and is in sharp contrast to the country's leadership under Thabo Mbeki, who questioned scientific consensus on HIV, costing the country upwards of 330000 lives. ${ }^{[35]}$ These divergent approaches hold important lessons for the world in our current global pandemic context: denialism and disregarding science costs lives. SA is currently the only African country participating in the global SOLIDARITY Trial, ${ }^{[36]}$ which will assess, among other interventions, the therapeutic efficacy of hydroxychloroquine and chloroquine against COVID-19. ${ }^{[37]}$ The results of the SOLIDARITY Trial will provide an evidentiary base for global policy-making.

\section{The way forward: The world needs the USA and the WHO}

The USA and the WHO have a proud history of aiding low- and middle-income countries in their responses to major diseases over the decades. The USA is, by far, the world's most generous provider of bilateral assistance in global health. ${ }^{[38]}$ Since 2009, the USA has provided more than USD100 billion in health assistance and nearly USD70 billion in humanitarian assistance, globally. ${ }^{[39]}$ By way of 
funding, the USA is currently leading the world's humanitarian and health assistance response to COVID-19. ${ }^{[38,39]}$ The USA is also the WHO's largest single government donor in the world by scale of assessment, ${ }^{[40]}$ and in terms of both assessed and voluntary contributions. ${ }^{[41]}$ The WHO African, South East Asian (which includes India) and Eastern Mediterranean (which includes Syria, Afghanistan, and Pakistan), regions are the biggest recipients of WHO funding. ${ }^{[42]}$ WHO support of these regions includes capacity building for emergency preparedness. ${ }^{[42]}$ As such, these regions stand to be disproportionately affected by the US suspension of WHO funding, just as COVID-19 prevalence in Africa, the most vulnerable of these regions, is ominously rising. ${ }^{[43]}$ While the USA may be the world's biggest health and humanitarian donor, the WHO plays an indispensable and irreplaceable role, globally. As the world faces its greatest public health threat since the $1918 \mathrm{H} 1 \mathrm{~N} 1$ pandemic, now is not the time to starve the WHO for political ends.

\section{Conclusions}

The USA and SA experiences underscore how easily a populist, hyperpartisan, fragmented global information ecosystem can undermine science and threaten health governance. If we are to end the COVID19 pandemic, the world needs scientific solidarity and strong moral leadership, not bluster, scapegoating and deflection. Undermining science and health governance for political expediency is dangerous, as it sows confusion and engenders distrust in public health officials. Populist and uninformed approaches to public health, scientific enquiry and global health governance are especially dangerous in a pandemic context, when accurate information and responsible advice are crucial for saving lives.

Funding. JAS is supported by the Centre for the AIDS Programme of Research in South Africa (CAPRISA), Durban, South Africa. He is also supported by the HIV Prevention Trial Network and the Bill and Melinda Gates Foundation. No specific funding was received for writing this article. The funders had no role in study design, data collection and analysis, decision to publish, or preparation of the manuscript. The views of the writer do not necessarily reflect the views of his funders or employers.

\section{Jerome Amir Singh}

Centre for the AIDS Programme of Research in South Africa (CAPRISA), University of KwaZulu-Natal, Durban, South Africa singhj9@ukzn.ac.za

1. World Health Organization. Statement on the second meeting of the International Health Regulations (2005) Emergency Committee regarding the outbreak of novel coronavirus (2019-nCoV). 30 January 2020. https://www.who.int/news-room/detail/30-01-2020-statement-on-the-second-meeting-of-theinternational-health-regulations-(2005)-emergency-committee-regarding-the-outbreak-of-novelcoronavirus-(2019-ncov) (accessed 15 April 2020).

2. Ghebreyesus TD. WHO Director-General's opening remarks at the media briefing on COVID-1911 March 2020. World Health Organization, 11 March 2020. https://www.who.int/dg/speeches/detail/ who-director-general-s-opening-remarks-at-the-media-briefing-on-covid-19---11-march-2020 (accessed 15 April 2020).

3. Interview. Tucker Carlson Tonight. Fox News, 18 March 2020. https://www.mediamatters.org/ media/3860681 (accessed 15 April 2020).

4. Grady D, Thomas K. Trump calls anti-malaria drug a 'game-changer' for coronavirus, but the FDA says it needs study. New York Times, 19 March 2020. https://www.nytimes.com/2020/03/19/health/ coronavirus-drugs-chloroquine.html (accessed 15 April 2020).

5. Riechmann DEB, Miller Z. White House debate heats up over using an anti-malaria drug to treat COVID-19. Time, 6 April 2020. https://time.com/5816219/white-house-hydroxychloroquine-covid/ (accessed 16 April 2020).

6. Cohen E, Cohen M. After Trump's statements about hydroxychloroquine, lupus and arthritis patients face drug shortage. CNN, updated 7 April 2020. https://edition.cnn.com/2020/04/07/health/ hydroxychloroquine-shortage-lupus-arthritis/index.html (accessed 15 April 2020).

7. Baker P, Rogers K, Enrich D, Haberman M. Trump's aggressive advocacy of malaria drug for treating Baker P, Rogers K, Enrich D, Haberman M. Trump's aggressive advocacy of malaria drug for treating
coronavirus divides medical community. New York Times, 6 April 2020. https://www.nytimes. coronavirus divides medical community. New York Times, 6 April 2020. https://www.n
com/2020/04/06/us/politics/coronavirus-trump-malaria-drug.html (accessed 16 April 2020).

8. Edwards E, Hillyard V. Man dies after taking chloroquine in an attempt to prevent coronavirus. NBC 8. Edwards E, Hillyard V. Man dies after taking chloroquine in an attempt to prevent coronavirus. NBC
News, 23 March 2020. https://www.nbcnews.com/health/health-news/man-dies-after-ingestingNews, 23 March 2020. https://www.nbcnews.com/health/health-news/mat
chloroquine-attempt-prevent-coronavirus-n1167166 (accessed 15 April 2020).
9. Guardian. Fauci: No evidence anti-malaria drug pushed by Trump works against virus. 5 April 2020. https://www.theguardian.com/world/2020/apr/05/coronavirus-fauci-trump-anti-malaria-drug (accessed 15 April 2020).

10. Alba D, Frenkel S. Medical expert who corrects Trump is now a target of the far right. New York Times, 28 March 2020. https://www.nytimes.com/2020/03/28/technology/coronavirus-fauci-trump-conspiracytarget.html?action=click\&module=RelatedLinks\&pgtype=Article (accessed 15 April 2020).

11. US Food and Drug Administration. Coronavirus (COVID-19) update: Daily roundup. 30 March US Food and Drug Administration. Coronavirus (COVID-19) update: Daily roundup. $30 \mathrm{March}$
2020. https://www.fda.gov/news-events/press-announcements/coronavirus-covid-19-update-daily2020. https://www.fda.gov/news-events/press-an
roundup-march-30-2020 (accessed 15 April 2020).

roundup-march-30-2020 (accessed 15 April 2020).
12. Piller C. Former FDA leaders decry emergency authorization of malaria drugs for coronavirus. Science, 7 April 2020. https://www.sciencemag.org/news/2020/04/former-fda-leaders-decry-emergency-
. Science, 7 April 2020. https://www.sciencemag.org/news/2020/04/for
authorization-malaria-drugs-coronavirus (accessed 15 April 2020)

13. Benner K, Shear MD. After threats, Anthony Fauci to receive enhanced personal security. New York Times, 1 April 2020. https://www.nytimes.com/2020/04/01/us/politics/coronavirus-fauci-security.
Time Times, 1 April 2020. https:

14. Coronaviridae Study Group of the International Committee on Taxonomy of Viruses. The species Severe acute respiratory syndrome-related coronavirus: Classifying 2019-nCoV and naming it SARSCoV-2. Nature Microbiol 2020;5:536-544. https://doi.org/10.1038/s41564-020-0695-Z

15. World Health Organization. Naming the coronavirus disease (COVID-19) and the virus that causes it. https://www.who.int/emergencies/diseases/novel-coronavirus-2019/technical-guidance/naming-thecoronavirus-disease-(covid-2019)-and-the-virus-that-causes-it (accessed 16 April 2020).

16. Chiu A. Trump has no qualms about calling coronavirus the 'Chinese Virus. That's a dangerous attitude, experts say. Washington Post, 20 March 2020. https://www.washingtonpost.com/nation/2020/03/20/ coronavirus-trump-chinese-virus/ (accessed 16 April 2020).

17. World Health Organization. WHO issues best practices for naming new human infectious diseases. 8 May 2015. https://www.who.int/mediacentre/news/notes/2015/naming-new-diseases/en/ (accessed 16 April 2020).

18. BBC. Coronavirus: Trump attacks 'China-centric' WHO over global pandemic. 8 April 2020. https:// www.bbc.com/news/world-us-canada-52213439 (accessed 16 April 2020).

19. BBC. Coronavirus: WHO chief urges end to 'politicisation' of virus. 9 April 2020. https://www.bbc. com/news/world-52224183 (accessed 15 April 2020)

20. Guardian. Politicising Covid-19 like playing with fire, WHO director general says after Trump attackvideo. 9 April 2020. https://www.theguardian.com/global/video/2020/apr/09/politicising-covid-19like-playing-with-fire-who-director-general-says-after-trump-attack-video (accessed 17 April 2020).

21. World Health Organization. WHO timeline - COVID-19. 8 April 2020. https://www.who.int/newsroom/detail/08-04-2020-who-timeline---covid-19 (accessed 17 April 2020).

22. Klein B, Hansler J. Trump halts World Health Organization funding over handling of coronavirus outbreak. CNN, 15 April 2020. https://edition.cnn.com/2020/04/14/politics/donald-trump-worldhealth-organization-funding-coronavirus/index.html (accessed 15 April 2020).

23. Collins M. The WHO and China: Dereliction of duty. Council on Foreign Relations, 27 February 2020. https://www.cfr.org/blog/who-and-china-dereliction-duty (accessed 17 April 2020).

24. Campbell C. 'A crime against humanity': Why Trump's WHO funding freeze benefits nobody. Time, 15 April 2020. https://time.com/5821122/who-funding-trump-covid19-coronavirus-china/ (accessed 15 April 2020).

25. Ramaphosa C. Measures to combat coronavirus COVID-19 epidemic. Presidency, South Africa, 15 March 2020. https://www.gov.za/speeches/statement-president-cyril-ramaphosa-measures-combatcovid-19-epidemic-15-mar-2020-0000 (accessed 15 April 2020).

26. Ramaphosa C. Escalation of measures to combat Covid-19 epidemic. Presidency, South Africa, 23 March 2020. http://www.dirco.gov.za/docs/speeches/2020/cram0323.pdf (accessed 16 April 2020).

7. Harding A. South Africa's ruthlessly efficient fight against coronavirus. BBC, 3 April 2020. https://www. bbc.com/news/world-africa-52125713 (accessed 15 April 2020).

28. Rickard C. Thumbs down from Constitutional Court for COVID-19 lockdown challenge. 30 March 2020. http://carmelrickard.co.za/thumbs-down-from-constitutional-court-for-covid-19-lockdownchallenge/ (accessed 15 April 2020).

29. Vincent D. Coronavirus: A Cameroon student on how he recovered. BBC, 17 February 2020. https:// Vincent D. Coronavirus: A Cameroon student on how he recovered.
www.bbc.com/news/world-africa-51502711 (accessed 15 April 2020).

30. Afriupdate staff. Chinese doctors reveals why African skin resists coronavirus. 24 March 2020. https:// . Afriupdate staff. Chinese doctors reveals why African skin resists coronavirus. $24 \mathrm{March} 2020$. https://
www.afriupdate.com/africa/chinese-doctors-reveals-why-african-skin-resists-coronavirus/ (accessed 15 April 2020).

31. World Health Organization. COVID-19 in the WHO African region. WHO Africa Dashboard. https:// World Health Organization. COVID-19 in the WHO African region. WHO After
www.afro.who.int/health-topics/coronavirus-covid-19 (accessed 17 April 2020).

32. Eligon J, Burch ADS, Searcey D, Oppel RA Jr. Black Americans face alarming rates of coronavirus

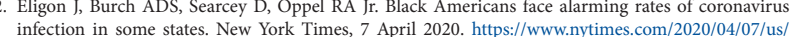
infection in some states. New York Times, 7 A
coronavirus-race.html (accessed 15 April 2020).

33. Ramaphosa C. Extension of coronavirus COVID-19 lockdown to the end of April. South African Ramaphosa C. Extension of coronavirus COVID-19 lockdown to the end of April. South African
Presidency, 9 April 2020. https://www.gov:za/speeches/president-cyril-ramaphosa-extension-coronavirusPresidency, 9 April 2020. https://www.gov.za/speeches/president-cyril-ramap
covid-19-lockdown-end-april-9-apr-2020-0000 (accessed 16 April 2020)

34. Evans S, Cowan K. Ramaphosa to make 'serious decisions' about lockdown based on science, possible economic repercussions. News24, 9 April 2020. https://www.news24.com/SouthAfrica/ News/ramaphosa-to-make-serious-decisions-about-lockdown-based-on-science-possible-economicrepercussions-20200409 (accessed 15 April 2020)

35. Chigwedere P, Seage GR, Gruskin S, Lee TH, Essex M. Estimating the lost benefits of antiretroviral drug use in South Africa. J Acquir Immune Defic Syndr 2008;49(4):410-415.

36. Roussi A, Maxmen A. African nations missing from coronavirus trials. Nature, 3 April 2020. https:// www.nature.com/articles/d41586-020-01010-7 (accessed 16 April 2020).

37. World Health Organization. 'Solidarity' clinical trial for COVID-19 treatments. https://www.who. int/emergencies/diseases/novel-coronavirus-2019/global-research-on-novel-coronavirus-2019-ncov/ solidarity-clinical-trial-for-covid-19-treatments (accessed 16 April 2020).

38. Office of the Spokesperson, US State Department. The United States is leading the humanitarian and health assistance response to COVID-19. US State Department, 27 March 2020. https://www.state. gov/the-united-states-is-leading-the-humanitarian-and-health-assistance-response-to-covid-19/ (accessed 16 April 2020).

39. Fabricius P. US adds almost $\$ 2 \mathrm{~m}$ to SA's fight against Covid-19. Daily Maverick, 17 April 2020. https:// www.dailymaverick.co.za/article/2020-04-17-us-adds-almost-2m-to-sas-fight-against-covid-19/ (accessed 16 April 2020).

40. World Health Assembly. Seventy-second World Health Assembly WHA72.12. Agenda item 15.5. Scale of assessments for 2020 - 2021. 8 May 2019. https://www.who.int/about/finances-accountability/ funding/A72_R12-en.pdf (accessed 16 April 2020).

1. World Health Organization. Funding by contributor. Updated until Q4-2019. https://open.who. int/2018-19/contributors/contributor (accessed 19 April 2020).

42. World Health Organization. Programme budget 2020 - 2021. https://www.who.int/about/financesaccountability/budget/WHOPB-PRP-19.pdf (accessed 16 April 2020).

43. BBC. Coronavirus: Africa could be next epicentre, WHO warns. 17 April 2020. https://www.bbc.com/ news/world-africa-52323375 (accessed 17 April 17 2020).

S Afr Med J 2020;110(6):445-446. https://doi.org/10.7196/SAMJ.2020.v110i6.14820 